\title{
Electrochemical synthesis of nanosized iron oxide-alumina system
}

\author{
A. F. DRESVYANNIKOV*, I. O. GRIGORYEVA, L. R. KHAYRULLINA, \\ E. V. PETROVA
}

\author{
Kazan National Research Technological University (KNRTU), Kazan 420015, Russia \\ Received: September 11, 2015; Revised: October 22, 2015; Accepted: October 28, 2015 \\ (C) The Author(s) 2016. This article is published with open access at Springerlink.com
}

\begin{abstract}
An electrochemical method for the synthesis of complex dispersed oxide system $\mathrm{Al}_{2} \mathrm{O}_{3}-\mathrm{Fe}_{2} \mathrm{O}_{3}$, based on the combined aluminum and iron anodic dissolution in aqueous solution containing chloride ions, has been suggested. The phase composition and morphology of $\mathrm{Al}_{2} \mathrm{O}_{3}-\mathrm{Fe}_{2} \mathrm{O}_{3}$ dispersed precipitate have been investigated by means of X-ray fluorescence, X-ray diffraction (XRD), and scanning electron microscopy (SEM). The influence of the electrolysis mode on the characteristics of the synthesized oxide system has been shown. It is found that the direct current (DC) mode allows us to adjust the phase correlation in the precipitate and to obtain a particle size which is two or more times smaller than the particle size of the samples synthesized by means of the alternating current $(\mathrm{AC})$.
\end{abstract}

Keywords: alumina; iron oxide; mixed oxide system; electrochemical synthesis; nanoparticles

\section{Introduction}

At present, the systems based on alumina and iron oxide attract significant interest due to the creation of new ceramics and composite materials with improved functional properties. Such mixed oxide systems and materials are widely used in various fields and industries. In the field of environmental protection, these materials are used as sorbents and agents in water and wastewater treatment, for example to reduce and remove phosphate ions [1,2], bromate ions [3], and other ions such as $\mathrm{Ni}^{2+}, \mathrm{NH}_{4}^{+}$[2], $\mathrm{Cr}^{6+}$ [4], and $\mathrm{Hg}^{2+}$ [5]. Nanocomposites based on a mixed oxide system $\mathrm{Al}_{2} \mathrm{O}_{3}-\mathrm{Fe}_{2} \mathrm{O}_{3}$ exhibit catalytic activity and selectivity in the oxidation and decomposition reactions of various organic pollutants [6,7], in the Fischer-Tropsch synthesis [8,9], and in technologies for producing

\footnotetext{
* Corresponding author.

E-mail: a.dresvyannikov@mail.ru
}

carbon nanotubes [10,11].

There are several successfully realized methods for the synthesis of complex oxide system $\mathrm{Al}_{2} \mathrm{O}_{3}-\mathrm{Fe}_{2} \mathrm{O}_{3}$ such as mechanochemical [10] and chemical methods based on precipitation from aqueous salt solution and subsequent hydrolysis of inorganic and organic derivatives of initial metals, in particular the sol-gel method [5,7], hydrothermal synthesis [1,12], a modified wet impregnation method [13], ultrasound-assisted co-precipitation method [3], Pechini process, and gel evaporation method [2] and others. However, the structure, composition and dispersion, and physical and physicochemical properties of the synthesized systems depend on the method of preparation thereof. Furthermore, chemical processes are often unstable and do not allow to obtain products of synthesis with reproduced and controlled characteristics. Therefore, to create materials with definite predetermined characteristics and controlled properties, it is necessary to develop more efficient approaches for preparing dispersed oxides with a certain range of dimensions and 
properties. One such alternative technique is the electrochemical generation of ceramic precursors, based on the anodic dissolution [14-16].

This method is characterized by a relatively simple equipment design and does not require the use of additional reagents. Besides, electrolysis allows us to realize the joint electrochemical oxidation of several metals of different nature. However, information on the synthesis of nanoparticles during the joint anodic dissolution of aluminum and iron is extremely insignificant, and the mechanism and regularities of their obtaining are rather an explored subject.

Therefore, the main objective of this paper is to use the process of joint aluminum and iron anodic dissolution in aqueous solution containing chloride ions to produce nanosized oxide system $\mathrm{Al}_{2} \mathrm{O}_{3}-\mathrm{Fe}_{2} \mathrm{O}_{3}$, and also to establish relationships between parameters of the electrochemical process and characteristics of the synthesized oxide system.

\section{Experimental procedures}

Electrochemical measurements were carried out in a conventional electrolytic cell with platinum auxiliary electrode, two $\mathrm{Ag} / \mathrm{AgCl}$ reference electrodes (for simultaneous measuring of $\mathrm{Al}$ and $\mathrm{Fe}$ potential), and working electrode using a computer controlled potentiostat-galvanostat model P-301M (Elins) and electrochemical station model Zive SP2 (WonATech). The working electrode was a hybrid electrode consisting of an electrical contact between plates of 99.5\% purity aluminum (ENAW-1050A) and 99.25\% purity iron (ARMCO-iron). The exposed apparent area of the each working plate (Al and $\mathrm{Fe}$ ) was $8 \mathrm{~cm}^{2}$, and distance between them was $20 \mathrm{~mm}$. Galvanostatic anodic polarization was performed at room temprature $\left(25^{\circ} \mathrm{C}\right.$ ) in $0.1 \mathrm{M} \mathrm{NaCl}$ (of analytical grade) solution. The test electrode was pre-treated by means of standard methods (chemical degreasing, pickling, multiple rinsing).

Synthesis of precursors of dispersed alumina-iron oxide system was performed via electrolysis in coaxial reactor of $500 \mathrm{~mL}$ (electrolyte volume $300 \mathrm{~mL}$ ) by DC and AC power supply (MATRIX, model MPS-7101). The central electrode (cathode) in the coaxial reactor was designed as steel wire X10CrNiTi18-10 (in the case of DC) and aluminum wire ENAW-1050A (in the case of $\mathrm{AC}$ ) with $2 \mathrm{~mm}$ diameter. Hybrid electrode was used as a soluble electrode (anode). The anode was combined of two aluminum and two iron plates (dimension of one plate working surface is $50 \mathrm{~mm} \times 40 \mathrm{~mm} \times 0.2 \mathrm{~mm}$ ), soldered to the copper wire. The distance between anode and cathode was $\sim 32 \mathrm{~mm}$, current density equaled to $25 \mathrm{~mA} / \mathrm{cm}^{2}$, and duration of electrolysis amounted to $2 \mathrm{~h}$ in each case.

For crystallization, the obtained precipitate was kept in a matrix solution for $48 \mathrm{~h}$, after which it was filtered and dried at $60{ }^{\circ} \mathrm{C}$ for $24 \mathrm{~h}$ in ambient atmosphere. Afterwards, the sample was calcined at $1100{ }^{\circ} \mathrm{C}$ (for $2 \mathrm{~h}$ ) in order to obtain oxides.

Phase analysis of the synthesized powders was investigated by X-ray diffraction (XRD) technique in a standard diffractometer (D2 PHASER) with monochromated $\mathrm{Cu} \mathrm{K} \alpha$ radiation $(\lambda=1.78897 \AA)$ operated at $30 \mathrm{kV}$ voltage and $10 \mathrm{~mA}$ current. Patterns of $\mathrm{Al}_{2} \mathrm{O}_{3}-\mathrm{Fe}_{2} \mathrm{O}_{3}$ nanopowders were recorded from $3^{\circ}$ to $130^{\circ}$ (in $2 \theta$ ) with a $0.05^{\circ}$ step width and a $1 \mathrm{~s}$ counting time per step. The identification of peaks on a diffractogram and the calculation of the elementary cell's parameters were carried out using the software complex DIFFRAC. EVA.

$\mathrm{X}$-ray fluorescence analysis of the powders was carried out using a portable X-ray fluorescence spectrometer S1 TITAN with maximum voltage of $50 \mathrm{kV}$ via data packet GeoChem General.

The morphology of $\mathrm{Al}_{2} \mathrm{O}_{3}-\mathrm{Fe}_{2} \mathrm{O}_{3}$ nanopowders was performed by scanning electron microscopy (SEM) using an EVEX Mini SEM SX-3000 with elemental analysis $(15 \mathrm{kV}, 10 \mu \mathrm{A})$. The local chemical composition, microstructure parameters, and size of nanoparticles were also characterized by using an SEM AURIGA CrossBeam with energy dispersive spectrometry INCA X-MAX (resolution $127 \mathrm{eV}$ ) operated at an acceleration voltage of $20 \mathrm{kV}$. In order to increase the conductivity of the samples, they were gold-palladium (60:40) coated $(15 \mathrm{~nm})$ using Quorum Q150T ES.

\section{Results and discussion}

According to modern presentations [17], at the contact of two conductors there is a transfer of electrons from the metal characterized by lower work function of an electron from a surface $\left(A=q_{\mathrm{e}} \Delta \varphi, \Delta \varphi\right.$ is the surface potential jump) in the metal with a larger work function. After the establishment of a thermodynamic equilibrium, contact potential difference (Volta effect) occurs $\left(\varphi=\psi / q=\left(A_{\mathrm{M} 1}-A_{\mathrm{M} 2}\right) / q\right)$ in a narrow boundary 
layer nearby contact plane, then the level of the Fermi energy in these metals is aligned and characterized by a single value.

Under conditions of anodic polarization of the hybrid electrode consisting of two electrically contacting metals, there is an outflow of electrons from the surface thereof. The Fermi levels of the contacting metals are close to each other; however, the metal surfaces facing the electrolyte differently interact with electrolyte ions. It is connected with various sorption capacity of the surface of naturally different metals, and also with different anode and related accompanying reactions $[18,19]$.

Therefore, the potentials of the contacting metals are maximally approximated compared with the potentials of individual metals in the same solution during anodic polarization. This is confirmed by the experimental data (Fig. 1). It may be seen that at zero or low polarization, potentials of the contacting metals are different from the potentials of the individual metals, apparently, by an amount that is equivalent to galvanic potential difference of these metals $[18,19]$.
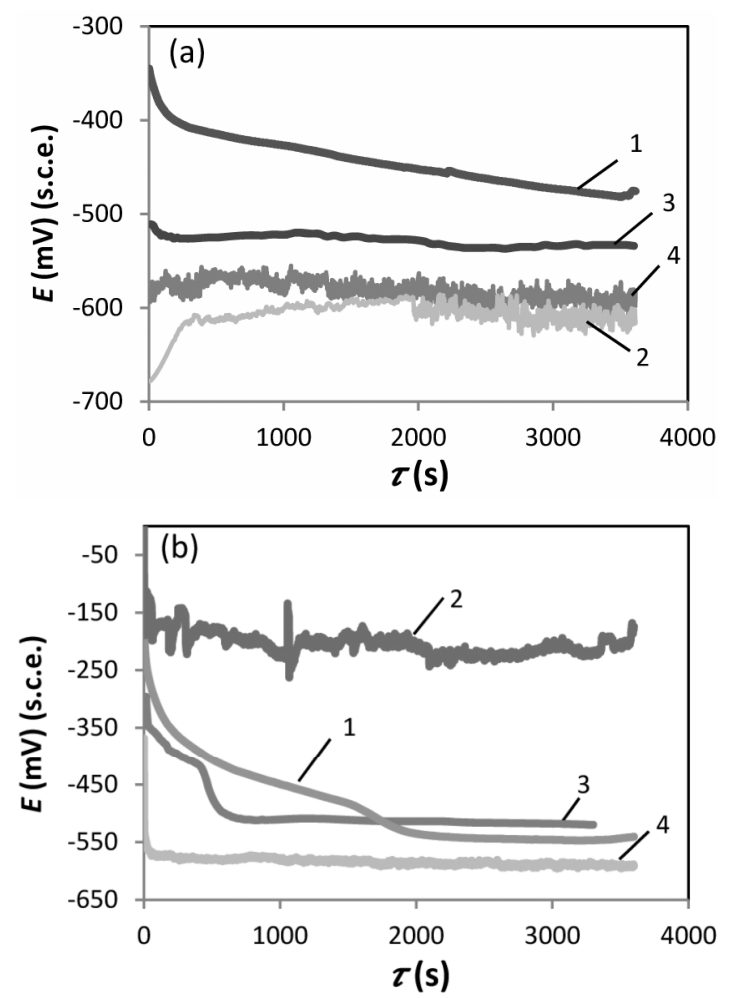

Fig. 1 Change of electrode potential of hybrid electrode in $10^{-1} \mathrm{M} \mathrm{NaCl}$ solution (a) at open circuit and (b) under anodic polarization for $j=2.5 \mathrm{~mA} / \mathrm{cm}^{2}$ : $1-\mathrm{Fe}$ (without contact); 2- $\mathrm{Al}$ (without contact); 3-Fe (in contact with $\mathrm{Al}$ ); 4- $\mathrm{Al}$ (in contact with $\mathrm{Fe}$ ). S.c.e., silver chloride electrode.
At the sufficiently high anodic polarization, the process of anodic dissolution (ionization) of metals occurs, accompanied by a significant change on the surface (Fig. 2). For example, the electrochemical dissolution of aluminum in an electrolyte containing sodium chloride is characterized by erosion of the grain boundary (Fig. 2(a)), whereas the electrochemical dissolution of iron is accompanied by more uniform change on the surface (Fig. 2(b)).

The oxidation rate of metals was determined by gravimetric method. For the oxidation rate $V_{\mathrm{ox}}$, the weight loss per unit of time $(1 \mathrm{~h})$, related to the unit of the electrode working surface $\left(8 \mathrm{~cm}^{2}\right)$, has been taken. In order to receive an ideal joint metal dissolution, the model sodium chloride solution of average concentration (most commonly used concentration $10^{-2} \mathrm{M} \mathrm{NaCl}$ ) was chosen. According to Fig. 3, the values of the oxidation rate of contacting metals are aligned and become comparable in comparison with that of the individual metals. Thus, aluminum and iron contacting with each other under anodic polarization in the aqueous solution of sodium chloride can dissolve at a different rate, depending on the current between the electrodes. Because of this fact, it may be stated as the basis method for adjusting the precipitate composition.
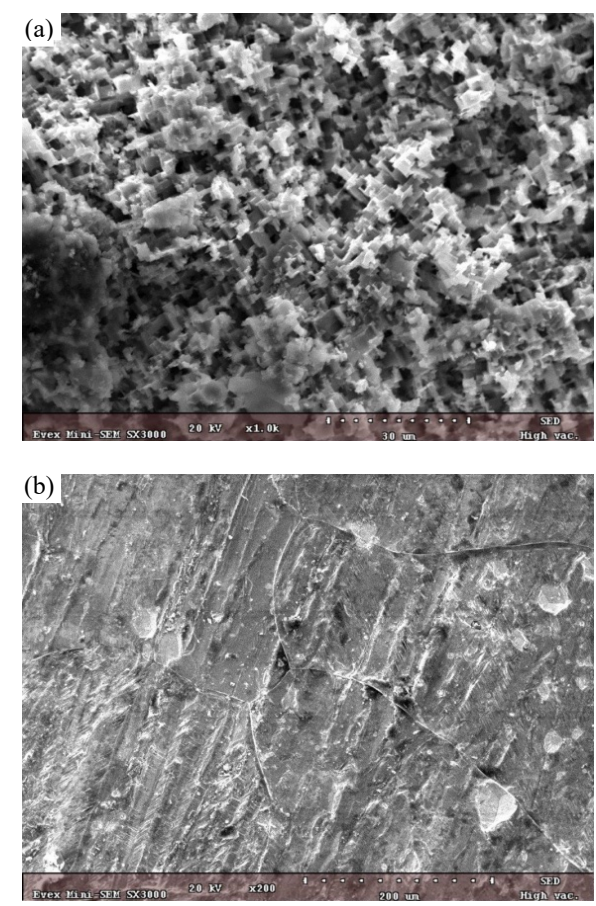

Fig. 2 SEM images of electrode surface of contacting metals after anodic polarization $\left(j=37 \mathrm{~mA} / \mathrm{cm}^{2}\right)$ in $10^{-1} \mathrm{M}$ $\mathrm{NaCl}$ solution: (a) $\mathrm{Al}$ (in contact with $\mathrm{Fe}$ ) and (b) $\mathrm{Fe}$ (in contact with Al). 


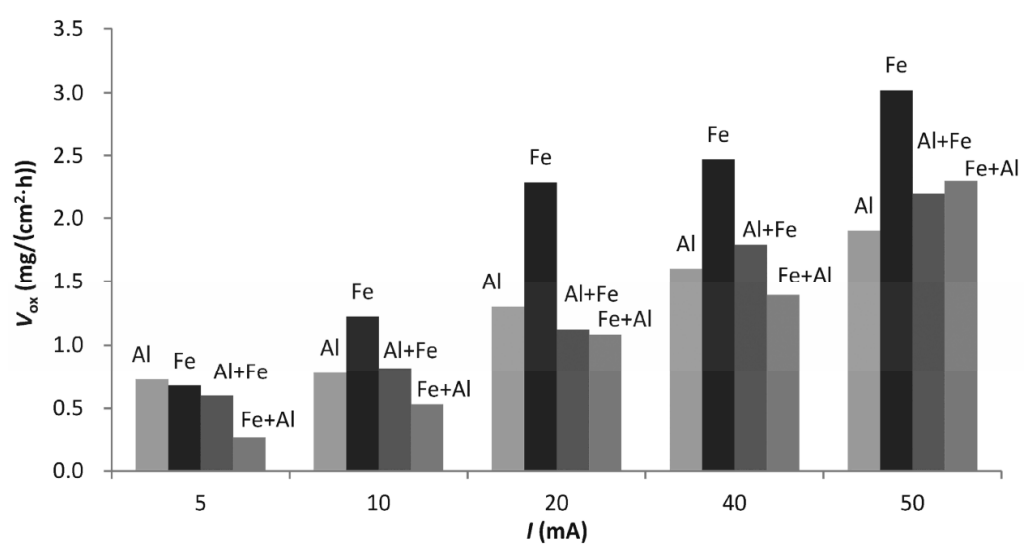

Fig. 3 Variation of the oxidation rate of the individual metals (Al, Fe) and contacting metals as components of the hybrid electrode $(\mathrm{Al}+\mathrm{Fe}, \mathrm{Fe}+\mathrm{Al})$ in $10^{-2} \mathrm{M} \mathrm{NaCl}$ solution with the current. $\mathrm{Al}+\mathrm{Fe}$-aluminum, in contact with iron; $\mathrm{Fe}+\mathrm{Al}$-iron, in contact with aluminum.

In order to obtain more significant effect and sufficient amount of the precipitate, the synthesis of precursors of dispersed oxide system was carried out in more concentrated solution of sodium chloride. It is well known that the dissolution rate is directly proportional to the concentration of the solution.

Joint product of electrochemical oxidation of aluminum and iron at DC in a solution of sodium chloride is a suspension of brown-greenish color. After drying for $2 \mathrm{~h}$ at $60{ }^{\circ} \mathrm{C}$, the precipitate's color becomes more saturated and changes to dark brown. In the case of precipitation using AC, it is light brown and after drying the precipitate's color remains unchanged.

The XRD patterns of the samples obtained by means of DC and AC electrolysis are shown in Figs. 4 and 5, respectively, and the results of XRD study as a function of heating temperature are summarized in Table 1. As shown in Fig. 4(a) for the sample obtained by means of

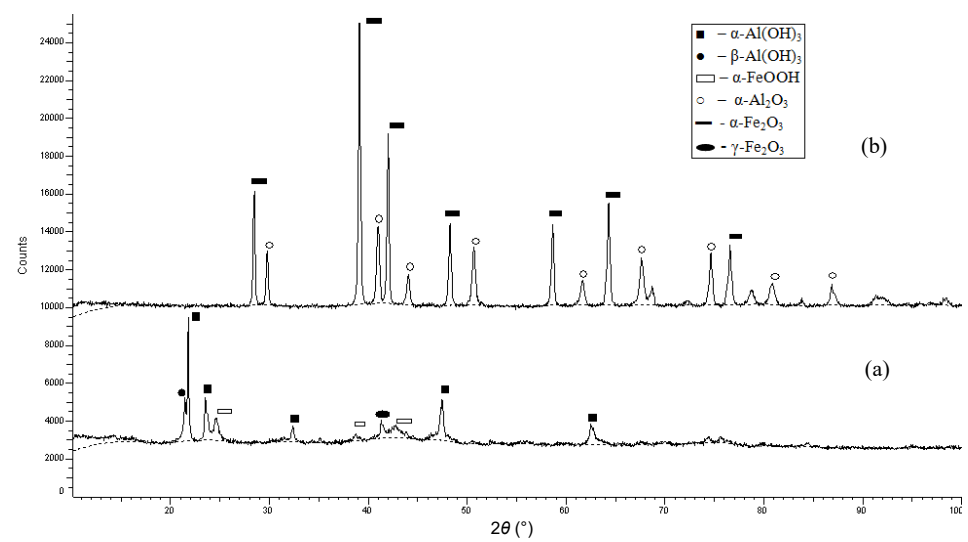

Fig. 4 XRD patterns of the samples obtained by means of DC electrolysis and subsequent calcination at (a) $60{ }^{\circ} \mathrm{C}$ and (b) $1100{ }^{\circ} \mathrm{C}$.

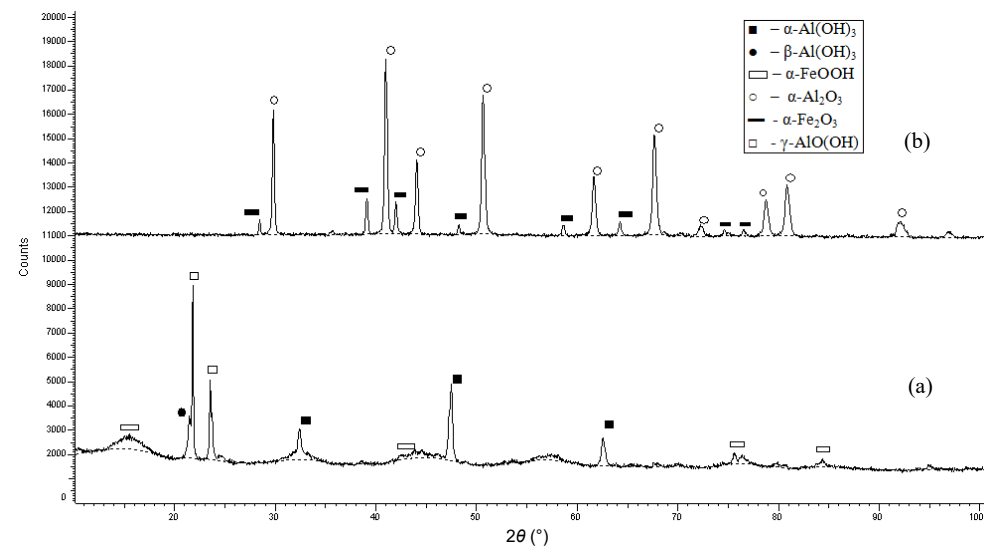

Fig. 5 XRD patterns of the samples obtained by means of AC electrolysis and subsequent calcination at (a) $60{ }^{\circ} \mathrm{C}$ and (b) $1100{ }^{\circ} \mathrm{C}$. 
Table 1 Phase composition of electrolysis products

\begin{tabular}{|c|c|c|c|c|c|c|c|c|}
\hline \multirow[b]{2}{*}{$\begin{array}{l}\text { Current } \\
\text { mode }\end{array}$} & \multirow{2}{*}{$\begin{array}{l}\text { Heating } \\
\text { temperature } \\
\left({ }^{\circ} \mathrm{C}\right)\end{array}$} & \multicolumn{7}{|c|}{ Phase composition (wt $\%)$} \\
\hline & & $\begin{array}{c}\text { Bayerite } \\
\alpha-\mathrm{Al}(\mathrm{OH})_{3}\end{array}$ & $\begin{array}{l}\text { Boehmite } \\
\gamma \text {-AlOOH }\end{array}$ & $\begin{array}{c}\text { Nordstrandite } \\
\beta-\mathrm{Al}(\mathrm{OH})_{3}\end{array}$ & $\begin{array}{c}\text { Corundum } \\
\alpha-\mathrm{Al}_{2} \mathrm{O}_{3}\end{array}$ & $\begin{array}{c}\text { Goethite } \\
\alpha \text {-FeOOH }\end{array}$ & $\begin{array}{c}\text { Hematite } \\
\alpha-\mathrm{Fe}_{2} \mathrm{O}_{3}\end{array}$ & $\begin{array}{c}\text { Maghemite } \\
\gamma-\mathrm{Fe}_{2} \mathrm{O}_{3}\end{array}$ \\
\hline \multirow{2}{*}{ DC } & 60 & 70 & - & 13 & - & 7.5 & - & 9.5 \\
\hline & 1100 & - & - & - & 53 & - & 47 & - \\
\hline \multirow{2}{*}{$\mathrm{AC}$} & 60 & 55 & 41 & 0.3 & - & 1.0 & - & - \\
\hline & 1100 & - & - & - & 95 & - & 5 & - \\
\hline
\end{tabular}

DC electrolysis and subsequent thermal treatment at $60{ }^{\circ} \mathrm{C}$, the positons of the diffraction lines of bayerite $\alpha-\mathrm{Al}(\mathrm{OH})_{3}$, nordstrandite $\beta-\mathrm{Al}(\mathrm{OH})_{3}$, as well as maghemite $\gamma-\mathrm{Fe}_{2} \mathrm{O}_{3}$ and goethite $\alpha$-FeOOH are indicated. According to data of quantitative phase content (Table 1), aluminum hydroxide is formed with the structure in the percentage of bayerite $70 \mathrm{wt} \%$ and nordstrandite $13 \mathrm{wt} \%$, and also iron oxyhydroxides are presented in the form of maghemite $(9.5 \mathrm{wt} \%)$ and goethite $(7.5 \mathrm{wt} \%)$. After the high temperature treatment $\left(1100{ }^{\circ} \mathrm{C}\right)$, alumina and iron oxides are presented in the powder composition with corundum $\alpha-\mathrm{Al}_{2} \mathrm{O}_{3}(53 \mathrm{wt} \%)$ and hematite $\alpha-\mathrm{Fe}_{2} \mathrm{O}_{3}(47 \mathrm{wt} \%)$ (Fig. 4(b), Table 1).

Precipitate formation due to the dissolution of aluminum and iron (ionization and hydration) under anodic half cycle of alternating current and its
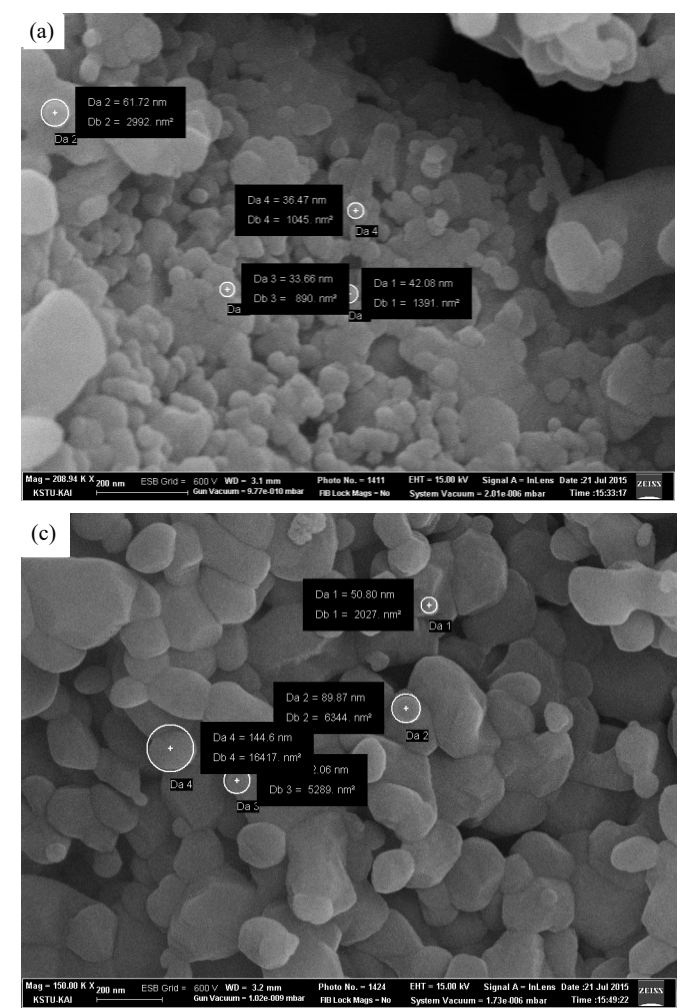

subsequent calcination at $60{ }^{\circ} \mathrm{C}$ (Fig. 5(a), Table 1) leads to the appearance of bayerite phase $(55 \mathrm{wt} \%)$ and aluminum oxyhydroxide with boehmite structure. Furthermore, it can also be seen the noticeable reduction of the iron oxyhydroxide content in the precipitate $(1.0 \mathrm{wt} \%)$, compared to DC electrolysis. After heat treatment $\left(1100{ }^{\circ} \mathrm{C}\right)$ as well as at $\mathrm{AC}$ electrolysis, metal oxides - corundum $\alpha-\mathrm{Al}_{2} \mathrm{O}_{3}(95 \mathrm{wt} \%)$ and hematite $\alpha-\mathrm{Fe}_{2} \mathrm{O}_{3}(5 \mathrm{wt} \%)$ are formed in the precipitate (Fig. 5(b), Table 1).

Of particular interest is the particle morphology of the obtained samples. From SEM photographs (Fig. 6), it is observed that the samples consist of irregular shaped aggregates, preferably of elongated shape, formed of spherical particles at or near the forms. The samples synthesized by means of DC electrolysis and heat treated at a temperature $1100{ }^{\circ} \mathrm{C}$ consist of
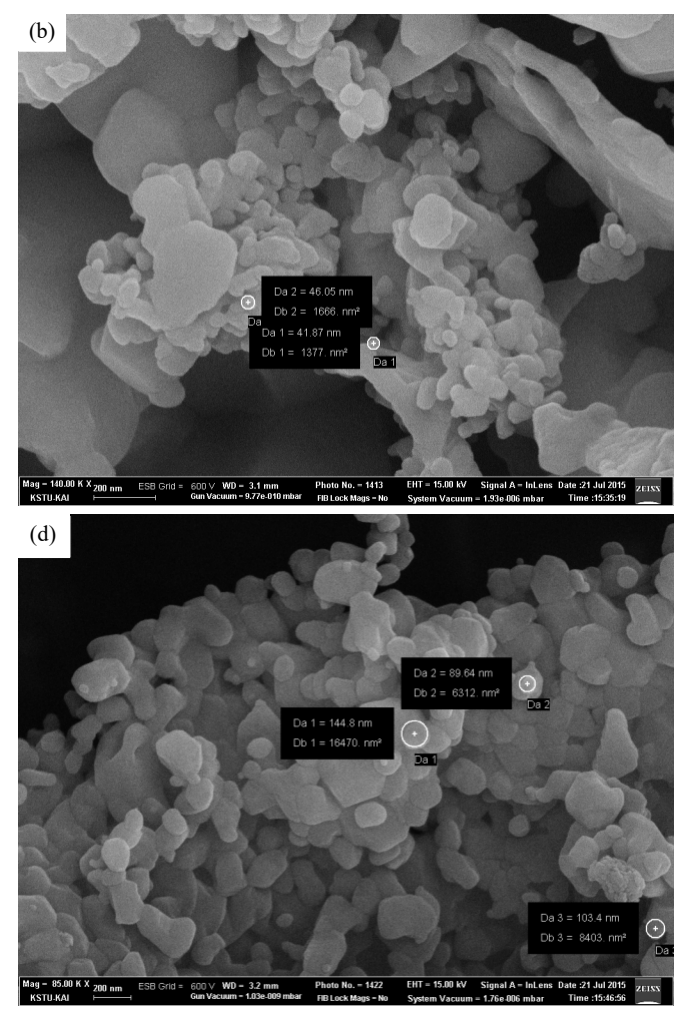

Fig. 6 SEM images of the samples obtained by means of (a) and (b) DC and (c) and (d) AC electrolysis (solution $10^{-1} \mathrm{M}$ $\mathrm{NaCl}$, current density $25 \mathrm{~mA} / \mathrm{cm}^{2}$, temperature $25^{\circ} \mathrm{C}$, duration of electrolysis $2 \mathrm{~h}$ ) and subsequent calcination at $1100{ }^{\circ} \mathrm{C}$. 
nanoparticles with sizes in the range of $35-45$ to 60 $75 \mathrm{~nm}$. In contrast, the samples obtained by means of $\mathrm{AC}$ electrolysis show larger particles and are in the size range of $60-80$ to $100-140 \mathrm{~nm}$. Thus, oxide system obtained by means of DC electrolysis shows a more compact structure consisting of smaller (in two or more times) particles. Moreover, it is perfectly obvious that the small particle size of the obtained samples remains unchanged even after high temperature treatment. Thereby, the synthesized system may be used as precursors in the process of producing ceramics and composite materials. Therefore, the system can be synthesized to find potential use as precursors in the process of producing composite materials and ceramics.

In order to obtain more information about chemical composition, microstructure parameters, and size of
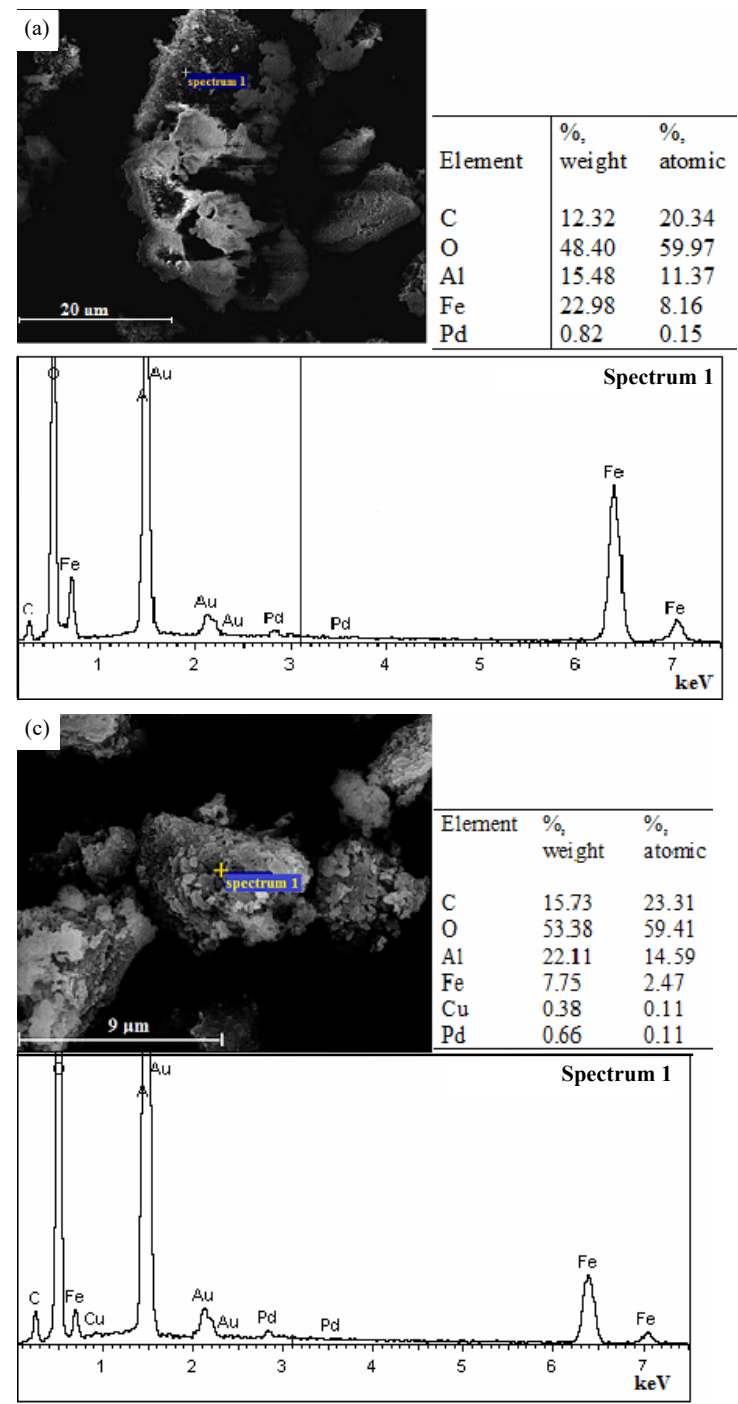

mixed oxide nanoparticles, we have carried out the local analysis by using an SEM AURIGA CrossBeam with energy dispersive spectrometry. These data (Fig. 7) confirm the difference in the properties of the samples obtained under different conditions of current. In the case of the sample prepared at $\mathrm{DC}$, the range of the iron content (wt\%) is $7-20$, while as obtained by $\mathrm{AC}$ is an average of 7.8. The content of aluminum in all the samples is comparable and is an average of $16-20 \mathrm{wt} \%$.

This is also confirmed by X-ray fluorescence analysis of the samples calcined at $1100{ }^{\circ} \mathrm{C}$. According to the data of elemental composition, the content of $\mathrm{Al}$ and $\mathrm{Fe}$ in the sample obtained by means of DC electrolysis and subsequent calcined at $1100{ }^{\circ} \mathrm{C}$ is $17.5 \%$ and $47.2 \%$, respectively, and the sample synthesized under nonequilibrium conditions is $38.3 \% \mathrm{Al}$ and $19.7 \% \mathrm{Fe}$.
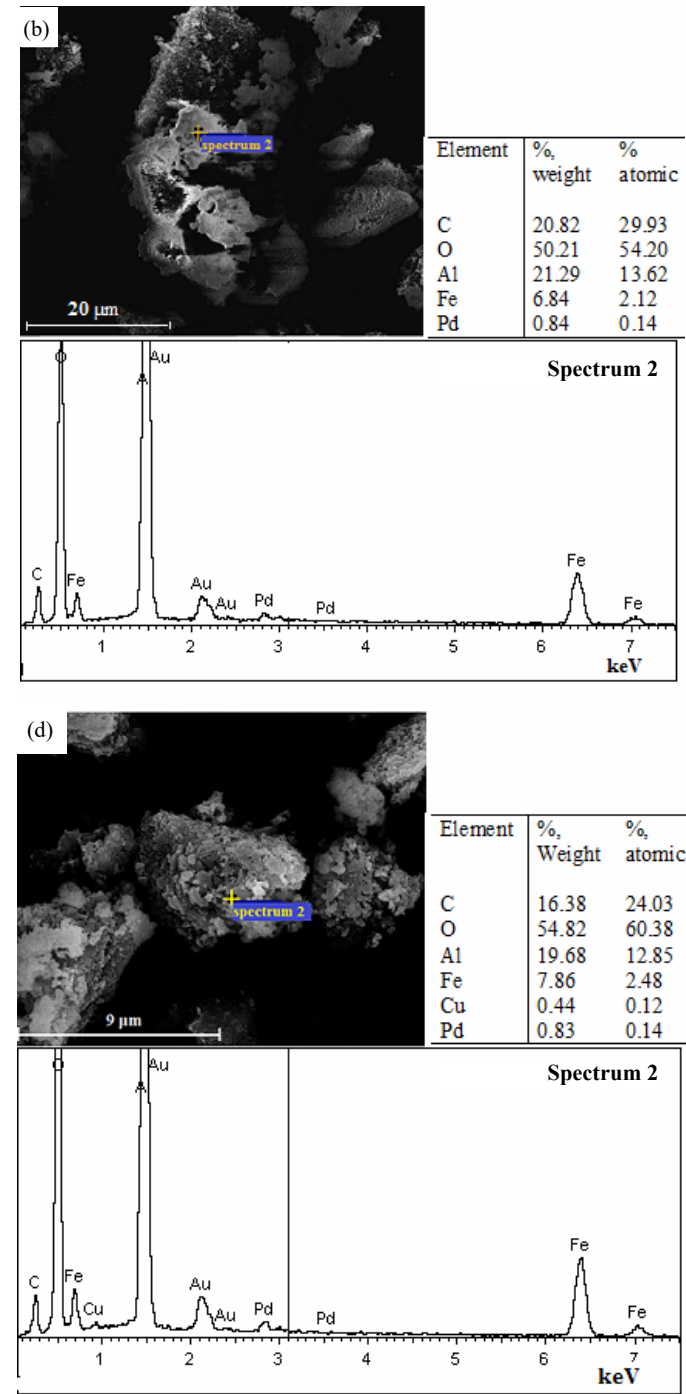

Fig. 7 Local analysis data of SEM images of the samples obtained by means of (a) and (b) DC and (c) and (d) AC electrolysis (solution $10^{-1} \mathrm{M} \mathrm{NaCl}$, current density $25 \mathrm{~mA} / \mathrm{cm}^{2}$, temprature $25^{\circ} \mathrm{C}$, duration of electrolysis $2 \mathrm{~h}$ ) and subsequent calcination at $1100{ }^{\circ} \mathrm{C}$. 


\section{Conclusions}

The mixed iron oxide-alumina nanosized system has been synthesized using anodic dissolution of the hybrid electrode $\mathrm{Al}-\mathrm{Fe}$ in the $10^{-1} \mathrm{M} \mathrm{NaCl}$ solution and subsequent heat treatment of the precipitate. It is found that the particle size of the sample obtained by means of DC electrolysis and subsequent calcination at $1100{ }^{\circ} \mathrm{C}$ is two or more times smaller than the particle size of the samples synthesized via nonequilibrium electrolysis. It is shown that in the case of the precipitate obtained by means of DC, after the high temperature treatment $\left(1100{ }^{\circ} \mathrm{C}\right)$, it is possible to achieve parity phase correlation (corundum 53\%, hematite $47 \%$ ). In contrast, in the case of the precipitate obtained by means of AC characterized adequate amiplitude, this ratio is changed in the direction of increased alumina content. It is also found that the particle size range after the high temperature heat treatment remains in the submicron range.

\section{Acknowledgements}

The authors thank the Ministry of Science and Education of Russia for financial support (an approved project No. 4.1584.2014/K of the competitive part of the government task to 2014-2016) and also Kazan National Research Technological University (KNRTU) for the possibility of using the equipment of the Center for Collective Use "Nanomaterials and Nanotechnologies".

\section{References}

[1] Chubar NI, Kanibolotskyy VA, Strelko VV, et al. Adsorption of phosphate ions on novel inorganic ion exchanges. Colloid Surface A 2005, 255: 55-63.

[2] Gulshan F, Kameshima Y, Nakajima A, et al. Preparation of alumina-iron oxide compounds by gel evaporation method and its simultaneous uptake properties for $\mathrm{Ni}^{2+}, \mathrm{NH}_{4}^{+}$and $\mathrm{H}_{2} \mathrm{PO}_{4}^{-}$. J Hazard Mater 2009, 169: 697-702.

[3] Zhong Y, Yang Q, Luo K, et al. Fe(II)-Al(III) layered double hydroxides prepared by ultrasound-assisted co-precipitation method for the reduction of bromate. J Hazard Mater 2013, 250-251: 345-353.

[4] Ajouyed O, Hurel C, Ammari M, et al. Sorption of Cr(VI) onto natural iron and aluminum (oxy)hydroxides: Effects of $\mathrm{pH}$, ionic strength and initial concentration. $J$ Hazard Mater 2010, 174: 616-622.

[5] Mahapatra A, Mishra BG, Hota G. Electrospun $\mathrm{Fe}_{2} \mathrm{O}_{3}-\mathrm{Al}_{2} \mathrm{O}_{3}$ nanocomposite fibers as efficient adsorbent for removal of heavy metal ions from aqueous solution.
J Hazard Mater 2013, 258-259: 116-123.

[6] Hsueh CL, Huang YH, Chen CY. Novel activated alumina-supported iron oxide-composite as a heterogeneous catalyst for photooxidative degradation of reactive black 5. J Hazard Mater 2006, 129: 228-233.

[7] Li FB, Li XZ, Liu CS, et al. Effect of alumina on photocatalytic activity of iron oxides for bisphenol A degradation. J Hazard Mater 2007, 149: 199-207.

[8] Park J-Y, Lee Y-J, Khanna PK, et al. Alumina-supported iron oxide nanoparticles as Fischer-Tropsch catalysts: Effect of particle size of iron oxide. J Mol Catal A: Chem 2010, 323: 84-90.

[9] Dong H, Xie M, Xu J, et al. Iron oxide and alumina nanocomposites applied to Fischer-Tropsch synthesis. Chem Commun 2011, 47: 4019-4021.

[10] Ding J, Liu BH, Dong ZL, et al. The preparation of $\mathrm{Al}_{2} \mathrm{O}_{3} / \mathrm{M}$ ( $\left.\mathrm{Fe}, \mathrm{Co}, \mathrm{Ni}\right)$ nanocomposites by mechanical alloying and the catalytic growth of carbon nanotubes. Composites Part B 2004, 35: 103-109.

[11] Alexiadis VI, Verykios XE. Influence of structural and preparation parameters of $\mathrm{Fe}_{2} \mathrm{O}_{3} / \mathrm{Al}_{2} \mathrm{O}_{3}$ catalysts on rate of production and quality of carbon nanotubes. Mater Chem Phys 2009, 117: 528-535.

[12] Mahapatra A, Mishra BG, Hota G. Adsorptive removal of Congo red dye from wastewater by mixed iron oxide-alumina nanocomposites. Ceram Int 2013, 39: $5443-5451$.

[13] Karakassides MA, Gournis D, Bourlinos AB, et al. Magnetic $\mathrm{Fe}_{2} \mathrm{O}_{3}-\mathrm{Al}_{2} \mathrm{O}_{3}$ composites prepared by a modified wet impregnation method. $J$ Mater Chem 2003, 13: 871-876.

[14] Stypula B, Starowicz M, Hajos M, et al. Electrochemical synthesis of $\mathrm{ZnO}$ nanoparticles during anodic dissolution of zinc in alcohols solvents. Arch Metall Mater 2011, 56: 287-292.

[15] Starowicz M, Starowicz P, Źukrowski J, et al. Electrochemical synthesis of magnetic iron oxide nanoparticles with controlled size. J Nanopart Res 2011, 13: 7167-7176.

[16] Starowicz M, Starowicz P, Stypula B. Alumina-based nanoparticles obtained by anodic dissolution of $\mathrm{Al}$ in electrolytes with alcohol solvents. J Solid State Electr 2014, 18: 3065-3071.

[17] Kittel C. Introduction to Solid State Physics, 7th edn. Wiley, 1996.

[18] Bockris IO, Reddy A, Gamboa-Aldeco M. Modern Electrochemistry. V.2A Fundamentalz of Eletrodics, 2nd edn. Kluwer Academic Publishers, 2002.

[19] Vetter KJ. Electrochemishe Kinetik, 2nd edn. Springer, 2014.

Open Access The articles published in this journal are distributed under the terms of the Creative Commons Attribution 4.0 International License (http://creativecommons. org/licenses/by/4.0/), which permits unrestricted use, distribution, and reproduction in any medium, provided you give appropriate credit to the original author(s) and the source, provide a link to the Creative Commons license, and indicate if changes were made. 